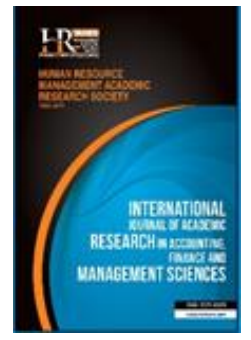

International Journal of Academic Research in Accounting, Finance and Management Sciences

Vol. 8, No.3, July 2018, pp. 17-25

E-ISSN: 2225-8329, P-ISSN: 2308-0337

(C) 2018 HRMARS

www.hrmars.com

To cite this article: Al Shbail, M.O. (2018). The Effect of Role Ambiguity and Role Conflict on Dysfunctional Audit Behaviour: Evidence from Jordan, International Journal of Academic Research in Accounting, Finance and Management Sciences 8 (3): 17-25.

\title{
The Effect of Role Ambiguity and Role Conflict on Dysfunctional Audit Behaviour: Evidence from Jordan
}

Mohannad Obeid AL SHBAIL

Al-Albayt University, Jordan, E-mail: seif198272@yahoo.com

\begin{abstract}
This paper explores dysfunctional audit behaviour among internal auditors specifically on its antecedents. The applicable literature is used to predict the relationships among stressors and dysfunctional audit behaviour. These relationships were then tested based on the survey outcomes from 187 internal auditors serving in Jordan. The results of structural equation model demonstrate the appropriate fit of the proposed conceptual model towards the data. The results demonstrate premature sign-off as the direct outcomes of role ambiguity and role conflict. This study also highlights the implications of these findings towards the management of companies and the potential future research.

Key words Dysfunctional audit

Received: 18 lun $2018 \quad$ (c) The Authors 2018

Revised: $20 \mathrm{Jul} 2018$ Published by Human Resource Management Academic Research Society (www.hrmars.com)

Accepted: $28 \mathrm{Jul} 2018$ This article is published under the Creative Commons Attribution (CC BY 4.0) license. Anyone may

Published Online: 09 Aug 2018 reproduce, distribute, translate and create derivative works of this article (for both commercial and noncommercial purposes), subject to full attribution to the original publication and authors. The full terms of this license may be seen at: http://creativecommons.org/licences/by/4.0/legalcode
\end{abstract}

\section{Introduction}

Internal audits are fundamental mechanisms for reliability (Weick and Sutcliffe, 2001) and continuous performance improvement (Ma'Ayan and Carmeli, 2016). They also influence the ethical reasoning process and ethical behaviour of the organization and its members (Bailey et al. 2003; Karcher, 1996; Lin et al., 2011; Stead et al., 1990). Recent legislation (e.g., the Sarbanes-Oxley Act, 2002 (SOX)) emphasizes the crucial role played by internal auditors in achieving compliance (Ma'ayan and Carmeli, 2016). In fact, exploring the impact of SOX on internal audit, Gray (2004) reported that after the implementation of SOX, internal auditors are viewed by management as their control experts. While the 1992 COSO Internal Control - Integrated Framework recognized that internal auditors played important roles in their organization, the updated 2013 COSO Framework further highlighted the critical roles of internal auditors, as "Internal auditors provide the third line of defense in assessing and reporting on internal control and recommending corrective actions or enhancements for management consideration and implementation; their position and compensation are separate and distinct of the business areas they review" (COSO 2013, p. 124).

Internal audit quality was viewed to be a major issue and as such, the concept constitutes a significant proportion of literature dedicated to internal audit quality. This is particularly true following the collapse of major companies like Enron, WorldCom, and Parmalat in the early 2000s. Such scandals created an urgent need for internal audit quality in terms of identifying irregularities including fraud (The Auditor's responsibility for detecting and reporting fraud and other illegal acts), and inconsistencies (Auditor should consider whether the conclusions drawn from different types of evidence are consistent with one another). 
Therefore, there is a call for studies to focus on audit quality in order to determine the factors contributing to and bringing about sub-standard audit quality. Thus, the present paper provides theoretical and empirical evidence regarding the factors impacting the quality of internal audit. However, prior experimental and survey research indicates that pressures in the audit environment lead to dysfunctional behaviours among individual auditors and results in lower audit quality (Al Shbail et al., 2018a, 2018b; Obeid et al., 2017). Thus, these pressures transcend the quality control mechanisms of a firm, affecting quality at the audit engagement level. Most prior research focused on the audit quality of external audits, but few researches focuses on the internal audit quality of public shareholding companies.

Azad (1994) found that the stressors produced significantly negative consequences on internal auditors such as an increase in premature sign-offs. Premature sign-offs widely existed among internal auditors (ibid). Ling and Akers (2010) state that a premature sign-off affects the quality of an internal audit and impacts an external audit if the external auditor relies upon the work of the internal audit department. On The other hand, in a study of 350 companies listed in the London Stock Exchange by Nehme (2013), it was shown that the majority of auditors exhibit dysfunctional behaviour in their work and that the majority of auditors knowingly commit dysfunctional behaviour for the sake of better performance. He noted also that some of dysfunctional behaviour acts are due to a misperception of the concept of dysfunctional behaviour during an audit assignment, whereas the pressures that come from audit (e.g. role ambiguity, role conflict, time deadline, time budget and performance evaluation) can lead to dysfunctional behaviours by internal auditors. Thus, a research problem is that there are certain stressors within a shareholding companies and that these stressors impact the health and work outcomes of internal auditors. It is therefore important that the various stressors (such as role ambiguity and role conflict) within companies should be identified to be able to put the necessary prevention mechanisms in place.

On other hand, studies concerning minimized audit quality practices concentrated largely on the direct relationship between stress antecedents/stressors (role ambiguity and role conflict) and minimized audit quality practices (Al Shbail et al., 2018a; Mohd Nor, 2011). The present work highlights the dysfunctional outcome of stressors (role ambiguity and role conflict). In relation to this, the determination the factors effects dysfunctional audit behaviour represents the next step towards a comprehensive appreciation of its role in the work environment and the potential steps to take in order to mitigate its effects.

\section{Literature review}

\section{Hypotheses development}

\section{Role ambiguity, role conflict and dysfunctional audit behaviour}

The internal auditor's dysfunctional behaviours effect on audit quality has become a top issue in the auditing profession. Such dysfunctional behaviours are displayed through various adverse behaviours like signing off an audit initiatives while skipping an audit step or highlighting its omission, employing unwise curtailments and or mitigating the work scope to under the par level, under-reporting of time expended on assignment, over-depending on the explanations and presentations of the auditee, failing to examine a crucial issue, failing to do follow-ups on the recommendations of audit (Azad, 1994).

Several studies in literature have been dedicated to examining premature sign-offs for external audit. These include Alderman and Deitrick (1982), Al-Shbiel (2016), Baldacchino et al. (2016), Hyatt and Prawitt (2011), Hyatt and Taylor (2013), Johansen and Christoffersen (2016), Mohd Nor et al. (2015), Reckers et al. (1997), Svanström (2016), Syazwan Karim et al. (2015) and Webb (2015). Azad's (1994) study is one of the two studies that investigated premature sign-offs among internal auditors by surveying members of the Institute of Internal Auditors (IIA) in the U.S. His study obtained a rate of response of $41 \%$, from 638 questionnaires, he received 262. His findings showed that premature sign-offs extensively rampant at $38 \%$, mostly in auditing compliance, operational auditing and financial auditing, internal control, inventory and fixed assets. In addition, Ahmad and Taylor's (2009) study found that stressors in internal audit environment (e.g., role ambiguity and role conflict) are significantly negatively related to commitment to independence.

According to Ling and Akers (2010), premature sign-offs can adversely influence audit quality work by internal auditors that in turn, may impact the external audit quality. Their sample comprised of 123 
individuals from the Institute of Internal Auditors (IIA) in the U.S., with a response rate of $3.4 \%$. They described operational auditing as an audit type that has the tendency to have premature sign offs, followed closely by financial auditing and compliance auditing. With regards to the top reasons of the occurrence of premature sign-offs, Azad (1994) and Ling and Akers (2010) showed six top reasons, which are; i) tendency to accept operating personnel explanation, ii) an audit step that seems unnecessary or immaterial, iii) insufficient supervision, iv) insufficient interaction with the supervisors, v) lack of certain technical knowledge and vi) limitations in time budget. On the whole, premature-sign offs seemed to permeate the auditing work and has been an issue for over thirty years.

Similarly, studies dedicated to public accounting literature refer to premature sign-off as the act in the work papers indicating that an audit step was completed without performing the needed work, or highlighting its omission (Coram et al., 2008). In fact, it has been a topic of interest for more than 3 decades and has been extensively examined in the context of the following countries; the US by Rhode (1978) and Shapeero et al. (2003), in the U.K. by Willett and Page (1996), in Malaysia by Hyatt and Taylor (2013) and Syazwan et al. (2015), in France by Herrbach (2001), in Australia by Coram et al. (2004) and in Ireland by Otley and Pierce (1996) and Pierce and Sweeney (2006). It can therefore be stated that premature sign-offs has been an issue that knows no borders among countries and that is crucial to the auditing profession.

In Rhode's (1978) related seminal study, he surveyed AICPA members concerning premature signoffs and majority of his respondents $(60 \%)$ conceded to conducting premature sign-offs during their career span. Studies of this caliber have delved into the incidence and antecedents of the topic - these include Alderman and Deitrick (1982), Buchman and Tracy (1982), Margheim and Pany (1986), Kelley and Margheim (1987; 1990), Raghunathan (1991), Margheim and Kelley (1992), Otley and Pierce (1996), Malone and Roberts (1996), Willett and Page (1996), Reckers et al. (1997), Herrbach (2001), Coram et al. (2003; 2008), Donnelly et al. (2003), Shapeero et al. (2003), Pierce and Sweeney (2004, 2005, 2006), Sweeney et al. (2010), Kelly et al. (2011), Hyatt and Prawitt (2011), Hyatt and Taylor (2013), Syazwan et al. (2015) and Kingori (2016). Further, some studies also informed participants that the audit staff member who committed the premature sign-off had a good work history in the firm prior to this incident, which called for future research could examine additional factors that may influence auditors premature signing off, such as role ambiguity (see Johnson, Kaplan and Reckers, 1998) and role conflict (see Al Shbail, 2018).

On other hand, within the workplace or organization, employees face role stress or role stressor which is a typical source of stress or stressor (Fisher, 2001). As explained by Montgomery et al. (1996), role stressors comprise role ambiguity and role conflict. Role conflict is born from the simultaneous occurrence of two or more role requirements, so that performance of one of them makes performance of the other more difficult (Katz and Kahn, 1978). This idea is also used by Fisher (2001), who even stresses the impossibility of not fulfilling one of the requirements. For Mohd Nor (2011), these requirements can also be perceived as important sources of stressful conditions in workplace. Role ambiguity is uncertainty about what a person responsible for a specific activity should do. For Singh and Rhoads (1991), lack of definitions or information regarding responsibilities, expectations and expected behaviors for a position or regarding its scope, can create role ambiguity. With respect to these two elements, Rebele and Michaels (1990) reported them to impact job outcomes and job-related attitudes.

Further, the nature of the Internal Auditor's daily work and the politics in the workplace creates the stressful situation on them. Firstly, contains internal auditor's role have inherent conflicts. According to Ahmad and Taylor (2009, p. 902), "role conflicts can derive from potential conflicting between their audit oversight role and the management consultative services role, as well as potential differences between directives of their professional body and demands of their organization's management". Secondly, conditions of change and complexity in the operating environment of internal auditors, including unclear work objectives, lack of feedback, regulatory complexity and technological change (Nuijten et al., 2015), have become favourably to role ambiguities (Ahmad and Taylor, 2009). Such role ambiguities or lack of clarity can create work tensions and lead to dysfunctional audit behaviour from the internal auditors. Thus, the study proposes that;

H1a: High perceived role ambiguity is related with an increase premature sign-off among internal auditors. 
H1b: High perceived role conflict is related with an increase premature sign-off among internal auditors.

\section{Methodology of research}

A survey questionnaire research design method is employed in this study because it is the most appropriate way to collect primary data to obtain beliefs, personal and social facts, and attitude (Neuman, 2006) and it gathers data when the study has confirmed the type of data to be gathered and the measurement of variables. Therefore, this study employed a survey questionnaire research design to gather data concerning the hypothesized relationships and can be categorized as a field with correlational research design or quantitative orientation (Kerlinger and Lee, 2000). According to Creswell (2009), a survey questionnaire is used to provide a quantitative documentation of attitudes among the population sample with the purpose of generalizing the study hypotheses. Accordingly, to achieve the objectives of this research, a quantitative survey questionnaire research approach will be conducted through selfadministrated questionnaire to measure the relationships between variables under investigation. In addition, rather than a longitudinal study, cross-sectional study was suitable to be utilized in this study for the reason for time limitation. In relation to that, many studies (Al-Shbiel, 2016; Al Shbail et al., 2018b; Chong and Monroe, 2015; Fogarty and Kalbers, 2006; Fogarty et al., 2000; Kalbers and Fogarty, 2005; Larson, 2004; Larson and Murff, 2006; Mohd Nor, 2011; Obeid et al., 2017; Paino, 2010; Smith and Emerson, 2017) of the relationship between stressors and behavioural outcomes in audit sector have used cross-sectional design.

In this study, the study population comprises of the internal auditors employed by the Jordanian shareholding firms obtained from the list of the Amman stock exchange of public shareholding companies. The study selected 248 firms from the list and categorized them into three types based on financial, services and industrial sectors. The partakers of this study comprise 385 internal auditors. Of the 385 selected respondents, only 187 provided useful responses in the survey conducted.

\subsection{Material}

This research was conducted with the aim to Examine and analyse the influence of role ambiguity and role conflict is directly on premature sign-off. The population in this study is all internal auditors who working in Jordanian public shareholding companies (not on license or experience). Samples were taken using the Smith (2013) formula, and a sample of 187 respondents was Obtained. Inferential statistical analyses were used to test the hypothesis of the research is structural equation modelling (PLS-SEM).

\section{Results}

\subsection{Measurement model}

In the analysis of PLS-SEM, the first step to assess the measurement model (outer model). The outer model comprises the component of the measurement, which determines how well the indicators (items) theoretically load and connect with the corresponding constructs. Table 1 present the factor loadings for the items and significance level of factor loadings respectively. These items were then used for further analysis in PLS-SEM. 
Table 1. Average value and outer loading every indicators

\begin{tabular}{lcccc}
\hline Construct & Items & Loadings & Mean & P-value \\
\hline \multirow{4}{*}{ Role Ambiguity } & RA1 & 0.848 & 4.45 & 0.000 \\
& RA2 & 0.870 & 4.57 & 0.000 \\
& RA4 & 0.854 & 5.22 & 0.000 \\
& RA5 & 0.837 & 4.66 & 0.000 \\
& RA6 & 0.871 & 4.73 & 0.000 \\
\hline \multirow{5}{*}{ Role Conflict } & RC1 & 0.914 & 4.89 & 0.000 \\
& RC2 & 0.836 & 4.80 & 0.000 \\
& RC4 & 0.804 & 5.03 & 0.000 \\
& RC5 & 0.789 & 4.83 & 0.000 \\
& RC6 & 0.841 & 4.52 & 0.000 \\
& RC7 & 0.875 & 4.87 & 0.000 \\
\hline \multirow{5}{*}{ Premature Sign-off } & PMSO1 & 0.888 & 4.73 & 0.000 \\
& PMSO2 & 0.842 & 4.74 & 0.000 \\
& PMSO4 & 0.827 & 5.17 & 0.000 \\
& PMSO9 & 0.807 & 4.75 & 0.000 \\
& PMSO10 & 0.803 & 4.65 & 0.000 \\
& & 0.758 & 4.63 & 0.000 \\
\hline
\end{tabular}

Based on Table1, factor 1 (Role Ambiguity) had one item which were loaded less than cut-off value (RA3), thus this item was deleted. Factor 2 (Role Conflict) had two factors that loaded significantly on the other factors, such as RC3 (0.168) and RC8 (0.243), thus these items were deleted from this factor. Five items were deleted from Factor 3 (Premature Sign-off), one of them mainly because of a cross-loading problem (PMSO11) and four items, PMSO3, PMSO6, PMSO7 and PMSO8 had factor loading below the cutoff value.

\subsection{Structural model}

In the second part of SEM analysis is the interpretation of structural models or structural models. Structural model presents the relationship between the study variables. Specifically, the ability of the model to predict and the relationship between latent variables are discussed. The rules of structural model assessment in PLS-SEM are not the same as for CB-SEM. In CB-SEM methods, the study uses goodness-of-fit standards to evaluate the structural model, whereas in PLS-SEM, the predictive capability of the model, particularly for predicting endogenous latent variables, is important. In the process of inner model assessment several stages, each of which has its own specific criteria, have been suggested by PLS-SEM scholars (Al-Shbiel et al., 2018; Chin, 1998; Hair et al., 2017; Henseler et al., 2016; Sarstedt et al., 2014).

This paper applied these key factors to assess the inner model. They are as follows: (i) endogenous constructs' coefficient of determination $\left(R^{2}\right)$, (ii) effect size and predictive relevance or cross-validated redundancy $\left(f^{2}\right.$ and $Q^{2}$ ), (iii) model fit and (iv) path coefficients and their significance (standard errors, significance levels, t-values and $p$ values). The results of the analysis are summarized in Table 2.

Table 2. Structural Model PLS-SEM

\begin{tabular}{|c|c|c|c|c|c|c|}
\hline \multirow{2}{*}{ Structural path } & \multirow{2}{*}{$\begin{array}{l}\text { Path coefficient } \\
\text { and (T Statistics) }\end{array}$} & \multirow{2}{*}{$\begin{array}{c}\text { Effect size } \\
\left(f^{2}\right)\end{array}$} & \multicolumn{2}{|c|}{$\begin{array}{c}\text { Percentile } 95 \% \text { confidence } \\
\text { intervals }\end{array}$} & \multirow{2}{*}{$\begin{array}{l}\text { P-Values } \\
(0.05 \%)\end{array}$} & \multirow{2}{*}{ Conclusior } \\
\hline & & & 95\%LL & $95 \%$ UL & & \\
\hline H1a: RA -> PMSO & $0.366(4.348)$ & 0.122 & $(0.143 ; 0.374)$ & & 0.000 & Supported \\
\hline H1b: RC -> PMSO & $0.208(3.176)$ & 0.105 & $(0.101 ; 0.283)$ & & 0.001 & Supported \\
\hline
\end{tabular}


Based on Table 2, there is a significant direct effect between role ambiguity (RA) and role conflict (RC) on premature sign-off (PMSO).

\subsection{Goodness of Fit}

The theoretical model of the conceptual framework of the study is said to fit if supported by empirical data. To know that the hypothetical model supported by empirical data presented in Table 3 below.

Table 3. Fit summary (SRMR)

\begin{tabular}{ccc}
\hline & Saturated Model & Estimated Model \\
\hline SRMR & 0.061 & 0.063 \\
\hline
\end{tabular}

For this study, the SRMR value for the reduced model generated by PLS-SEM is 0.061 can be referred in Table 3. Here, the value linked with the composite model SRMR reported by PLS is used due to the fact that the inner model contains the reflective as well as the formative constructs. As can be seen, the value is less than 0.08 as passable cut-off threshold for PLS-path model fit (Al-Shbiel et al., 2018; Henseler et al., 2016; Hu \& Bentler, 1998). This means that the substantial difference between the theoretical model and empirical correlation matrix does not exist. In other words, the value of 0.061 denotes the sufficient fit between the data set and theoretical model (Henseler et al., 2016).

\section{Conclusions and recommendations}

Despite a recent growing interest in internal audits (Coetzee and Lubbe, 2014; Everett and Tremblay, 2014; Neu et al., 2013; Pizzini et al., 2015; Roussy and Brivot, 2016), the concept of internal audit quality is, however, difficult to define or describe, and there is still little consensus on how to measure it. Roussy and Brivot (2016) suggest that internal audit quality is more polysemous and complex than previously acknowledged. Hence, the purpose of this study was to test whether dysfunctional audit behaviour is a determinant of internal audit quality. It is also suggested that certain stressors that exist in the auditing environment have significant negative implications toward internal auditors' professional behaviours.

Based on the analysis it can be concluded that there is a significant direct effect between role ambiguity and role conflict on premature sign-off. Marked by positive coefficient indicates that the high levels of role ambiguity and role conflict will lead to premature sign-off among internal auditors. In addition, by revealing the relationship between stressors and premature sign-off, internal audit managers and directors should be aware of the job stress that is inherent in the nature of an internal auditor's work. They should then take steps to reduce job stressors for both male and female employees who show early signs of dysfunctional behaviours because of its significant impact on the quality of internal auditing.

\section{References}

1. Ahmad, Z., \& Taylor, D. (2009). Commitment to independence by internal auditors: the effects of role ambiguity and role conflict. Managerial Auditing Journal, 24(9), 899-925.

2. Al-Shbiel, S. O. (2016). An Examination the Factors Influence on Unethical Behaviour among Jordanian external auditors: Job Satisfaction as a mediator. International Journal of Academic Research in Accounting, Finance and Management Sciences, 6(3), 285-296.

3. Al-Shbiel, S. O., Ahmad, M. A., Al-Shbail, A. M., Al-Mawali, H., \& Al-Shbail, M. O. (2018). The mediating role of work engagement in the relationship between organizational justice and junior accountants' turnover intentions. Academy of Accounting \& Financial Studies Journal, 22(1), 1-23.

4. Al Shbail, M. (2018). Antecedents of burnout and its relationship to internal audit quality. Doctor of Philosophy of Accounting, Universiti Malaysia Terengganu, Malaysia.

5. Al Shbail, M., Salleh, Z., \& Mohd Nor, M. (2018a). Antecedents of burnout and its relationship to internal audit quality. Business and Economic Horizons, 14(4), accepted.

6. Al Shbail, M., Salleh, Z., \& Mohd Nor, M. (2018b). The effect of ethical tension and time pressure on job burnout and premature sign-off. Journal of Business and Retail Management Research, 12(4), 43-53. 
7. Alderman, C. W., \& Deitrick, J. W. (1982). Auditors' perceptions of time budget pressures and premature sign-offs: A replication and extension. Auditing: A Journal of Practice \& Theory, 1(2), 54-68.

8. Azad, A. N. (1994). Time budget pressure and filtering of time practices in internal auditing: a survey. Managerial Auditing Journal, 9(6), 17-25.

9. Bailey, A. D., Gramling, A. A., \& Ramamoorti, S. (2003). Research opportunities in internal auditing: Institute of Internal Auditors Research Foundation.

10.Baldacchino, P. J., Tabone, N., Agius, J., \& Bezzina, F. (2016). Organizational Culture, Personnel Characteristics and Dysfunctional Audit Behavior. IUP Journal of Accounting Research \& Audit Practices, 15(3), 34-63.

11.Buchman, T. A., \& Tracy, J. A. (1982). Obtaining responses to sensitive questions: Conventional questionnaire versus randomized response technique. Journal of Accounting Research, 263-271.

12.Chin, W. W. (1998). The partial least squares approach for structural equation modeling. In G. A. Marcoulides (Ed.), Modern methods for business research. New York: Psychology Press.

13.Chong, V. K., \& Monroe, G. S. (2015). The impact of the antecedents and consequences of job burnout on junior accountants' turnover intentions: a structural equation modelling approach. Accounting \& Finance, 55(1), 105-132.

14.Coetzee, P., \& Lubbe, D. (2014). Improving the Efficiency and Effectiveness of Risk-Based Internal Audit Engagements. International Journal of Auditing, 18(2), 115-125.

15.Coram, P., Glavovic, A., Ng, J., \& Woodliff, D. R. (2008). The moral intensity of reduced audit quality acts. Auditing: A Journal of Practice \& Theory, 27(1), 127-149.

16.Coram, P., Ng, J., \& Woodliff, D. R. (2004). The effect of risk of misstatement on the propensity to commit reduced audit quality acts under time budget pressure. Auditing: A Journal of Practice \& Theory, 23(2), 159-167.

17.Creswell, J. (2009). Research design: Qualitative, quantitative, and mixed methods approaches: SAGE Publications, Incorporated.

18.Donnelly, D. P., Quirin, J. J., \& O'Bryan, D. (2003). Auditor acceptance of dysfunctional audit behavior: An explanatory model using auditors' personal characteristics. Behavioral Research in Accounting, 15(1), 87-110.

19.Everett, J., \& Tremblay, M.-S. (2014). Ethics and internal audit: Moral will and moral skill in a heteronomous field. Critical Perspectives on Accounting, 25(3), 181-196.

20.Fisher, R. T. (2001). Role stress, the type A behavior pattern, and external auditor job satisfaction and performance. Behavioral Research in Accounting, 13(1), 143-170.

21.Fogarty, T. J., \& Kalbers, L. P. (2006). Internal auditor burnout: An examination of behavioral consequences Advances in Accounting Behavioral Research (pp. 51-86): Emerald Group Publishing Limited.

22.Fogarty, T. J., Singh, J., Rhoads, G. K., \& Moore, R. K. (2000). Antecedents and consequences of burnout in accounting: Beyond the role stress model. Behavioral Research in Accounting, 12, 31-68.

23.Gray, G. L. (2004). Changing internal audit practices in the new paradigm: the Sarbanes-Oxley Environment: Inst of Internal Auditors.

24.Hair, J., F, Hult, G., Ringle, C., \& Sarstedt, M. (2017). A primer on partial least squares structural equation modeling (PLS-SEM) $\left(2^{\text {nd }} e d\right)$ : Thousand Oaks, CA: Sage.

25. Henseler, J., Hubona, G., \& Ray, P. (2016). Using PLS path modeling in new technology research: updated guidelines. Industrial Management \& Data Systems, 116(1), 2-20.

26. Herrbach, O. (2001). Audit quality, auditor behaviour and the psychological contract. European Accounting Review, 10(4), 787-802.

27.Hu, L.-t., \& Bentler, P. M. (1998). Fit indices in covariance structure modeling: Sensitivity to underparameterized model misspecification. Psychological methods, 3(4), 424-453.

28.Hyatt, T. A., \& Prawitt, D. F. (2011). The organizational response to the discovery of false sign-off. International Journal of Disclosure and Governance, 8(1), 43-61.

29.Hyatt, T. A., \& Taylor, M. H. (2013). The Effects of Time Budget Pressure and Intentionality on Audit Supervisors' Response to Audit Staff False Sign-off. International Journal of Auditing, 17(1), 38-53.

30.Johansen, T. R., \& Christoffersen, J. (2016). Performance Evaluations in Audit Firms: Evaluation Foci and Dysfunctional Behaviour. International Journal of Auditing. Int. J. Audit., doi: 10.1111/ijau.12079. 
31.Johnson, E. N., Kaplan, S. E., \& Reckers, P. M. (1998). An examination of potential gender-based differences in audit managers' performance evaluation judgments. Behavioral Research in Accounting, 10, 47.

32.Kalbers, L. P., \& Fogarty, T. J. (2005). Antecedents to internal auditor burnout. Journal of managerial issues, 17(1), 101-118.

33.Karcher, J. N. (1996). Auditors' ability to discern the presence of ethical problems. Journal of Business Ethics, 15(10), 1033-1050.

34.Katz, D., \& Kahn, R. L. (1978). The social psychology of organizations (2 ${ }^{\text {nd }}$ ed.). New York: John Wiley \& Sons.

35.Kelley, T., \& Margheim, L. (1987). The effect of audit billing arrangement on underreporting of time and audit quality reduction acts. Advances in Accounting, 5(4), 22-33.

36.Kelley, T., \& Margheim, L. (1990). The impact of time budget pressure, personality, and leadership variables on dysfunctional auditor behavior. Auditing-A Journal Of Practice \& Theory, 9(2), 21-42.

37.Kelly, T., Margheim, L., \& Pattison, D. (2011). Survey on the differential effects of time deadline pressure versus time budget pressure on auditor behavior. Journal of Applied Business Research (JABR), 15(4), 117-128.

38.Kerlinger, F., \& Lee, H. (2000). Foundations of Behavioral Research: Wadsworth, Thomson Learning. Northridge, $C A$.

39.Kingori, J. (2016). Burnout and Auditor Work Behaviours in Tanzanian Public Accounting Firms. Business Management Review, 11(1), 65-97.

40.Larson, L. (2004). Internal auditors and job stress. Managerial Auditing Journal, 19(9), 1119-1130.

41.Larson, L., \& Murff, E. (2006). An analysis of job stress outcomes among bank internal auditors: environmental job stressors, including politics and rewards, were more stress producing than workload stressors such as time pressure. Bank Accounting \& Finance, 19(4), 39-44.

42.Lin, S., Pizzini, M., Vargus, M., \& Bardhan, I. R. (2011). The role of the internal audit function in the disclosure of material weaknesses. The Accounting Review, 86(1), 287-323.

43.Ling, Q., \& Akers, M. (2010). An Examination of Underreporting Of Time And Premature Signoffs By Internal Auditors Review of Business Information Systems, 14(4), 37-48.

44.Ma'Ayan, Y., \& Carmeli, A. (2016). Internal Audits as a Source of Ethical Behavior, Efficiency, and Effectiveness in Work Units. Journal of Business Ethics, 137(2), 347-363.

45.Malone, C. F., \& Roberts, R. W. (1996). Factors associated with the incidence of reduced audit quality behaviors. Auditing: A Journal of Practice \& Theory, 15(2).

46.Margheim, L., \& Kelley, T. (1992). The perceived effects of fixed fee audit billing arrangements. Accounting horizons, 6(4), 62-72.

47.Margheim, L., \& Pany, K. (1986). Quality-control, premature signoff, and underreporting of timesome empirical-findings. Auditing-a journal of practice \& theory, 5(2), 50-63.

48. Mohd Nor, M. N. (2011). Auditor stress: antecedents and relationships to audit quality. (Ph.D. dissertation, Edith Cowan University, Australia)

49.Mohd Nor, M. N., Smith, M., Ismail, Z., \& Nahar, H. S. (2015). Unethical Audit Behaviour among Malaysian Auditors: An Exploratory Study. Pertanika Journal of Social Sciences \& Humanities, 23(Special Issue), 59-71.

50.Montgomery, C. D., Blodgett, J. G., \& Barnes, J. H. (1996). A model of financial securities salespersons' job stress. Journal of Services Marketing, 10(3), 21-38.

51.Nehme, R. (2013). Dynamics of Audit Quality: Behavioural Approach and Governance Framework: UK Evidence. Durham University.

52.Neu, D., Everett, J., \& Rahaman, A. S. (2013). Internal auditing and corruption within government: The case of the Canadian Sponsorship Program. Contemporary Accounting Research, 30(3), 1223-1250.

53.Neuman, W. L. (2006). Social Research Methods: Qualitative and Quantitative Approaches (6th edn) Australia.

54.Obeid, M., Salleh, Z., \& Mohd Nor, M. (2017). The Mediating Effect of Job Satisfaction on The Relationship Between Personality Traits and Premature Sign-off. Academy of Accounting and Financial Studies Journal, 21(2), 1-17. 
55.Otley, D. T., \& Pierce, B. J. (1996). Auditor time budget pressure: consequences and antecedents. Accounting, Auditing \& Accountability Journal, 9(1), 31-58.

56.Paino, H. (2010). Impairment of audit quality: an investigation of factors leading to dysfunctional audit behavior. Edith Cowan University.

57.Pierce, B., \& Sweeney, B. (2006). Perceived adverse consequences of quality threatening behaviour in audit firms. International Journal of Auditing, 10(1), 19-39.

58.Pizzini, M., Lin, S., \& Ziegenfuss, D. E. (2015). The impact of internal audit function quality and contribution on audit delay. Auditing: A Journal of Practice \& Theory, 34(1), 25-58.

59.Raghunathan, B. (1991). Premature signing-off of audit procedures: An analysis. Accounting horizons, 5(2), 71-90.

60.Rebele, J. E., \& Michaels, R. E. (1990). Independent auditors' role stress: Antecedent, outcome, and moderating variables. Behavioral Research in Accounting, 2(1), 124-153.

61.Reckers, P. M., Wheeler, S. W., \& Wong-On-Wing, B. (1997). A comparative examination of auditor premature sign-offs using the direct and the randomized response methods. Auditing, 16(1), 69-78.

62.Rhode, J. G. (1978). Survey on the influence of selected aspects of the auditor's work environment on professional performance of certified public accountants. Issued as the Independent Auditor's Work Environment: A Survey. New York, NY: AICPA.

63.Roussy, M., \& Brivot, M. (2016). Internal audit quality: a polysemous notion? Accounting, Auditing \& Accountability Journal, 29(5), 714-738.

64.Sarstedt, M., Ringle, C. M., Smith, D., Reams, R., \& Hair, J. F. (2014). Partial least squares structural equation modeling (PLS-SEM): A useful tool for family business researchers. Journal of Family Business Strategy, 5(1), 105-115.

65.Shapeero, M., Chye Koh, H., \& Killough, L. N. (2003). Underreporting and premature sign-off in public accounting. Managerial Auditing Journal, 18(6/7), 478-489.

66.Singh, J., \& Rhoads, G. K. (1991). Boundary role ambiguity in marketing-oriented positions: A multidimensional, multifaceted operationalization. Journal of Marketing Research, 328-338.

67.Smith, K. J., \& Emerson, D. J. (2017). An analysis of the relation between resilience and reduced audit quality within the role stress paradigm. Advances in Accounting, 37, 1-14.

68.Smith, S. (2013). Determining sample size: How to ensure you get the correct sample size.

69.Stead, W. E., Worrell, D. L., \& Stead, J. G. (1990). An integrative model for understanding and managing ethical behavior in business organizations. Journal of Business Ethics, 9(3), 233-242.

70.Svanström, T. (2016). Time pressure, training activities and dysfunctional auditor behaviour: evidence from small audit firms. International Journal of Auditing, 20(1), 42-51.

71.Sweeney, B., Arnold, D., \& Pierce, B. (2010). The impact of perceived ethical culture of the firm and demographic variables on auditors' ethical evaluation and intention to act decisions. Journal of Business Ethics, 93(4), 531-551.

72.Syazwan Karim, M., Paino, H., Abd Jabar, F., Pauzi, M., Farahah, N., \& Abu Bakar, S. A. N. (2015). Factors Contributing to Premature Sign-Off of Audit Procedure: Evidence from Malaysia. Advanced Science Letters, 21(5), 1243-1246.

73.Webb, K. J. (2015). The Moderating Effect of Perceived Ethical Leadership on Reduced Audit Quality Behaviors doctoral thesis, University of Texas at Arlington, United State.

74.Weick, K., \& Sutcliffe, K. (2001). Managing the unexpected: Assuring high performance in an age of uncertainty. San Francisco: Wiley, 1(3), 5.

75. Willett, C., \& Page, M. (1996). A survey of time budget pressure and irregular auditing practices among newly qualified UK chartered accountants. The British Accounting Review, 28(2), 101-120. 